\title{
Role of Root Colonizing Trichoderma Species in Management of Alternaria Leaf Blight of Asalio (Lepidium sativum L.) Caused by Alternaria alternata
}

\author{
M. Surya Prakash Reddy ${ }^{1^{*}}$, Vibha $^{2}$ and Sunil Kumar Pandey ${ }^{3}$ \\ ${ }^{1}$ Department of Plant Pathology, ${ }^{2}$ Plant Physiology, ${ }^{3}$ Plant Breeding, Jawaharlal Nehru \\ Krishi Vishwa Vidyalaya, Jabalpur 482 004, Madhya Pradesh, India \\ *Corresponding author
}

\section{Keywords \\ Root colonizing \\ Trichoderma, \\ Alternaria leaf \\ blight, Asalio \\ (Lepidium sativum \\ L.), Alternaria \\ alternata}

\section{Article Info}

Accepted:

17 June 2018

Available Online:

10 July 2018

\section{A B S T R A C T}

Lepidium sativum an important medicinal plant with immense pharmacological properties has been observed to be generally affected by many fungal pathogens in India particularly Alternaria alternata characterized by the appearance of brown necrotic spots on the leaf margin affecting the herb yield. Root colonizing PGPF (plant growth promoting fungi) have been reported to produce substances such as plant hormones to allow plants to utilize decomposing organic matter through mineral solubilization and to suppress plant pathogens in the rhizosphere by antagonistic mechanisms, such as the production of hydrolytic enzymes, aggressive mycoparasitism, competition for saprophytic colonization, and the induction of plant systemic resistance. The effect of six species of Trichoderma isolated from different crops of rhizosphere and their efficacy was assessed under in vitro and in vivo conditions. Under in-vitro conditions, they were screened for their qualitative traits viz., IAA production, phosphorus solublizing activity and ammonia producing activity. Biomass determination and bioefficacy tests were performed against Alternaria alternata. The six Trichoderma species viz., T. koningii, T.ressei-1 and T.longibrachiatum produced higher quantity of IAA. The tri-calcium phosphate solublization activity was recorded only with T.asperellum and T. harzianum. The T. koningii and T.ressi-2 medium ammonium producer while rest four Trichoderma species were minimum ammonium producer. Out of six species of Trichoderma highest suppression was recorded with T.ressei-2 towards the Alternaria alternata. However, the highest inhibition was recorded by metabolite of $T$. asperellum isolates that corresponds to 38.75 percent reduction in mycelia growth when growth medium was non-amended with $\mathrm{znso}_{4}$. Similarly, the highest inhibition was recorded in metabolite of T.ressei-2 isolates when growth medium was amended with $\mathrm{znsO}_{4}$. The highest biomass production of $T$. ressei-2 was recorded with $\mathrm{ZnsO}_{4}$ amended medium while the highest biomass of $T$. ressei-1 was recorded with non $\mathrm{ZnsO}_{4}$ amended growth medium. The effect of inoculation of fungal bioagent along with FYM and $\mathrm{Znso}_{4}$ was found significant on relative water content (RWC), chlorophyll content, membrane stability index (MSI) and disease index under in-vivo conditions. The minimum disease incidence of Alternaria leaf blight was recorded with the soil application of either T.ressei-2+FYM + $\mathrm{znsO}_{4}$ or T.ressei-1+FYM + $\mathrm{znsO}_{4}$. 


\section{Introduction}

Lepidium sativum also known as common cress, garden cress, garden pepper cress, pepper grass or pepperwort (english) and chandrasur, chansur (hindi); is an annual herb, belonging to Brassicaceae family. Lepidium seed is an important source of iron, folic acid, calcium and vitamins $\mathrm{A}, \mathrm{C}$ and $\mathrm{E}$. The seed also contains arachidic, linolic fatty acids and rich in protein $(2.6 \mathrm{~g} / 100 \mathrm{~g})$, whereas the leaves are an excellent source of vitamin A, C and folate (Doke and Guha, 2014). However, chandrasur an important medicinal plant with significant pharmacological properties has been observed to be generally affected by many fungal pathogens in India. Among them A. alternata causes severe leaf spot in the northern Indian plains. Alternaria leaf spot disease symptoms in $L$. sativum are characterized by the appearance of brown necrotic spots on the leaf margin. The necrosis spreads towards the midrib and as a result the leaf curls up and dries, affecting herbal yield. Root colonizing fungi in the genus Trichoderma frequently increases root growth development, crop productivity, resistance to abiotic stresses and the uptake and use of nutrients (Harman et al., 2004a). Many studies have shown an increase in growth and $\mathrm{P}$ uptake by plants through the inoculation of PSMs (one of the component of PGPF) in pot experiments (Vassilev et al., 2006) and as well as in field conditions (Valverde et al.,2006). Therefore, to overcome the menace of this pathogen, the Plant Growth Promoting Fungi (PGPF) with special reference to Trichoderma species have been used to manage the disease with following objectives;

Isolation and characterization of Plant Growth Promoting Fungi (PGPF) with special reference to Trichoderma species

Establishment of bio-control potential by against Alternaria alternata by Trichoderma species under In-vitro and In-vivo Conditions

\section{Materials and Methods}

Collection of diseased specimens and purification of the pathogen

Diseased Asalio plants exhibiting typical symptoms of Alternaria alternata infection were collected from the experimental field of AICRP on Medicinal Aromatic Plants and Betelvine of Jawaharlal Nehru Krishi Vishwa Vidyalaya $\quad\left(22^{\circ} 49^{\prime}-2^{0} \quad 80^{\prime} \mathrm{N}\right.$; $\quad 78^{\circ} 21^{\prime}-$ $\left.80^{\circ} 58^{\prime} \mathrm{E}\right)$, Jabalpur in the Central India during 2016-17. The affected disease portions of plant (like leaf, branches etc.) were cut with the help of sharp razor and rinsed with sterilised water to remove traces of dirt. These were surface sterilised by dipping in 1:1000 mercuric chloride solution for one minute and washed twice with sterile water. These pieces were transferred aseptically to sterilised Petridishes containing solidified PDA in a laminar air flow. The Petri-dishes were incubated at $25 \pm 2^{\circ} \mathrm{C}$. The growth of fungus was observed after 72 hours and isolations were made from developing colonies for further study. The pathogen was further purified through single spore method and sub-cultured on PDA slants and kept at $4{ }^{\circ} \mathrm{C}$ for further use.

\section{Treatment details of mycoflora used under} in-vitro and in-vivo studies

\begin{tabular}{|l|}
\hline Trichoderma Species \\
\hline T. koningii \\
\hline T.ressei-1 \\
\hline T. harzianum \\
\hline T.asperellum \\
\hline T.longibrachiataum \\
\hline T.ressei-2 \\
\hline Control \\
\hline
\end{tabular}

The field experiment was conducted with six treatments and three replications in randomized block design with plot size of two square meters during 2016-17. The beneficial fungi (@2 $\mathrm{ml} / \mathrm{m}^{2}$ ) were combined with $\mathrm{ZnSO}_{4}$ (@ 200ppm) were applied in soil. 


\section{IAA producing activity}

The presence of IAA-like substances was detected by following the method of Sarwar and Kremer (1995) in L-tryptophan agar. The fungi were grown on L-tryptophan agar medium in triplicate and incubated at $28 \pm 2^{\circ} \mathrm{C}$ for seven days in the dark. After seven days of incubation, the fungus grown on L-tryptophan agar medium was added with freshly prepared Salkowsky reagent (Sarwar and Kremer, 1995) in triplicate, for each bioagent grown on Petri dish and incubated in the dark for $30 \mathrm{~min}$ for development of pink colour. The amount of IAA production was expressed by + and sign. The - indicates no IAA production;+ faint pink colour and small amount of IAA production; ++ pink colour and medium amount of IAA production; +++ dark pink colour and high amount of IAA production.

\section{Phosphorus solublizing activity}

Phosphate solubilizing fungi were isolated by the dilution plate methods modified by Johnson et al., (1959)on PVK medium (Pikovskaya, 1948) with tri-calcium phosphate as insoluble inorganic phosphate source. Rose Bengal as bacteriostatic agent was added (1 0 $\mathrm{ml} / \mathrm{l}$ ) at concentration 1/15000 (Smith and Daws, 1944). Total fungal counts were calculated in triplicate after 7 days of isolation by multiplying average number of colonies in each plate with inverted dilution factors. The isolates were identified on the basis of colony morphology, spore characteristics and microscopic examination according to Moubasher (Moubasher, 1993).

Pikovskaya's medium with rose Bengal addition was prepared. Sterilized PVK media was poured into sterilized plates, after solidification of the media, fungal strains were placed on the center of plates under aseptic conditions. They were incubated at $28 \pm 2^{\circ} \mathrm{C}$ for 5 days with continuous observation for colony diameter. The $\mathrm{P}$ solubilizing fungi were detected by the formation of clear halo around their colonies. The performance of each fungus was marked by assigning them + and - sign. The - indicates no phosphorus solublization, + small amount of phosphorus was dissolved, ++ medium amount of phosphorus was dissolved and +++ high amount of phosphorus was dissolved.

\section{Ammonia producing activity}

For the detection of ammonia production, all species were grown in Petri-dishes containing peptone water agar (peptone: $10.0 \mathrm{~g}$; $\mathrm{NaCl}$ : $5.0 \mathrm{~g}$; distilled water: $1000 \mathrm{ml} ; 7.0 \mathrm{pH}$ ). The Petri-dishes were inoculated with seven days old culture of bioagent's and incubated at $30 \pm 1^{0} \mathrm{C}$ for 5 days.

The accumulation of ammonia was detected by adding Nessler's reagent $(0.5 \mathrm{ml}$ per plate $)$. A faint yellow colour indicated a small amount of ammonia, and deep yellow to brownish colour indicated medium to maximum production of ammonia.

\section{Determination of biomass production}

The testing of biomass production by the beneficial fungi was done by growing them on potato dextrose broth and amended with and without $\mathrm{znSO}_{4}$ (@200ppm) prepared in 100 $\mathrm{ml}$ Erlenmeyer flask and final $\mathrm{pH}$ was adjusted to 6.5 to 7.0. They were later inoculated aseptically with $5 \mathrm{~mm}$ actively grown culture disc of the fungus. Three replications were maintained. The entire set up was incubated for 7 days at $25^{\circ} \mathrm{C}$ to attain maximum growth and sporulation. Mycelial mat was obtained by filtering on pre-weighed filter paper (Whatman filter paper no.1) (as fresh weight) and dried in hot air oven at $60^{\circ} \mathrm{C}$ until a constant weight (dry weight) was obtained (Hall and Bell 1961). 
Evaluation of antagonistic potential of beneficial fungi through dual culture technique

The antagonistic potentials of bioagents such as Trichoderma species were evaluated against test pathogen (Alternaria alternata) through dual culture technique (Denis and Webster, 1971). Per cent inhibition of growth of the pathogens was calculated by using the following formula.

$$
\begin{aligned}
& \text { Inhibition }= \\
& \begin{array}{c}
\text { Radial growth } \\
\text { in control }(\mathrm{C})
\end{array} \quad \overline{\text { in }} \begin{array}{r}
\text { Radial growth } \\
\text { theatment }(\mathrm{T})
\end{array}
\end{aligned}
$$

Radial growth in control(C)

Per cent inhibition $=$ Inhibition $\times 100$

Assessment of culture filtrates of beneficial mycoflora added with or without $\mathrm{ZnSO}_{4}$ by poison food technique

Effect of culture filtrate of Ttrichoderma species combined with and without $\mathrm{ZnSO}_{4}$ was assessed against mycelial growth of Alternaria alternata by Dennis and Webster (1971) method. Filtrate of antagonist(s) culture in PDA broth grown for 10 days with or without addition of $\mathrm{ZnSO}_{4}$ (@ 200ppm).

Fungi-toxicity of beneficial fungi was expressed as inhibition of radial growth of test pathogen by following formula:

Percentage of inhibition $=\frac{\mathrm{R} 1-\mathrm{R} 2}{\mathrm{R} 1} \times 100$

R1 - Radial growth of the pathogen in control plate,

R2 - Radial growth of the pathogen in test plate

\section{Relative water content (RWC)}

Measurements of RWC (Barrs and Weatherly, 1962) were performed on leaves collected from Asalio plants. Leaves were always collected from the mid section of either branches or seedlings, in order to minimize age effects. Individual leaves were first removed from the stem with tweezers. A sharp razor blade was used to cut the leaf base and leaves were then immediately weighed (fresh mass, FM). The FM obtained from each sample was minimum 1 gram. In order to obtain the turgid mass (TM), leaves were floated in distilled water inside a closed Petri dish. At the end of the imbibition period, leaf samples were placed in a pre-heated oven at $80^{\circ} \mathrm{C}$ for $48 \mathrm{~h}$, in order to obtain the dry mass (DM). Values of FM, TM, and DM were used to calculate $\mathrm{RWC}$, using the following equation:

$\operatorname{RWC}(\%)=[(\mathrm{FM}-\mathrm{DM}) /(\mathrm{TM}-\mathrm{DM})] \times 100$

A leaf sample was made up of ten to fifteen leaves, collected from the same branch or seedling. For data analysis, each leaf sample was treated as an experimental unit. The experimental units were organized following a Random block design.

\section{Chlorophyll content index}

Chlorophyll Content Index was estimated through the portable chlorophyll meter (Peng et al., 1992). Fully expanded leaf sample from three places of each plant of different treatments has been selected for estimation of chlorophyll content index.

The mean of triplicate readings taken using SPAD-502 (SPAD-502, Minolta, Japan) around the mid-point near the midrib of each sample were recorded for different treatment of Asalio leaf and averaged. 


\section{Membrane stability index (MSI)}

The membrane stability index (MSI) was determined according to the method of Deshmukh et al., (1991). Leaf discs (0.2 g) of control and treated plants were thoroughly washed in running tap water and double distilled water and were placed in $20 \mathrm{ml}$ of doubled distilled water at $40{ }^{0} \mathrm{C}$ for 30 minutes, after that electrical conductivity (EC) was recorded by conductivity bridge (C1).

Subsequently, the same samples were placed in boiling water bath $\left(100^{\circ} \mathrm{C}\right)$ for 10 minutes and the electrical conductivity was recorded (C2). The membrane stability index was calculated by using the formula:

$\mathrm{MSI}=[1-\mathrm{C} 1 / \mathrm{C} 2] \times 100$

\section{Results and Discussion}

Qualitative characterization of beneficial attributes of plant growth promoting rhizosphere fungi

The three Trichoderma species viz., $T$. koningii,T.ressei-1 and T.longibrachiatum produced higher quantity of IAA as shown by development of dark pink colour of growth medium while rest three (T.asperellum,T. harzianum andT.ressei-2) were minimum IAA producer. The tri-calcium phosphate solublization activity was recorded only with T.asperellum andT. harzianum. The $T$. koningii and T.ressi-2 medium ammonium producer while rest four Trichoderma species were minimum ammonium producer.(table.1)

Screening of different Trichoderma species against Alternaria alternata under in-vitro conditions

The effects of six species of Trichoderma were assessed against mycelia growth of A.alternata and all the species were found highly suppressive towards the test pathogen. The suppression of mycelia growth of test pathogen by different species of Trichoderma varied between $21.98 \mathrm{~mm}$ to $27.61 \mathrm{~mm}$. The highest $(21.98 \mathrm{~mm})$ suppression was recorded with $\mathrm{T}_{6}($ T.ressei-2) which was statistically at par with the suppression recorded with $\mathrm{T}_{2}$ $(22.24 \mathrm{~mm})$. The highest $(40.28 \%)$ inhibition percent was recorded with $\mathrm{T}_{6}($ T.ressei-2). while least (24.99 percent) with $\mathrm{T}_{1}$ (T.koningii).(table.2)

Evaluation of bioefficacy of culture filtrates of Trichoderma species against Alternaria alternata under in-vitro conditions

The inhibition of mycelia growth of Alternaria alternata under poison food technique by culture filtrate of different Trichoderma species varied within themselves and also with time. The highest $(23.75 \mathrm{~mm})$ inhibition was recorded with $\mathrm{T}_{4}$ that correspond to 38.75 percent mycelia growth reduction followedby $\mathrm{T}_{6}(25.58 \mathrm{~mm})$ and $\mathrm{T}_{2}(25.68 \mathrm{~mm})$ that were identical to each other in growth inhibition.

The growth of the pathogen had increased with time but increase was comparatively slower from 72 hours $(27.22 \mathrm{~mm})$ to 96hours (28.66mm) hours but significantly increased at 120hours.(table.3)

Evaluation of bioefficacy of culture filtrates of Trichoderma species amended with $\mathrm{ZnSO}_{4}$ against Alternaria alternata

The culture filtrate of different Trichoderma species amended with $\mathrm{ZnSO}_{4}$ had significantly inhibited the mycelial growth of A. alternata when tested under poison food technique (Table4.7) at different time intervals. The maximum $(23.75 \mathrm{~mm})$ inhibition was recorded with $\mathrm{T}_{6}$ followed by $\mathrm{T}_{4}(24.61 \mathrm{~mm})$ while least inhibition was recorded withT 3 (28.54). Almost similar inhibition was recorded with $\mathrm{T}_{1}(27.96 \mathrm{~mm}), \mathrm{T}_{5}(27.80 \mathrm{~mm})$ and $\mathrm{T}_{2}$ (27.41). The mycelia growth of test pathogen increased from 48 hours $(25.96 \mathrm{~mm})$ to 120 hours (30.85mm) (Table 4). 
Plate.1 Plant parts affected by Alternaria alternata

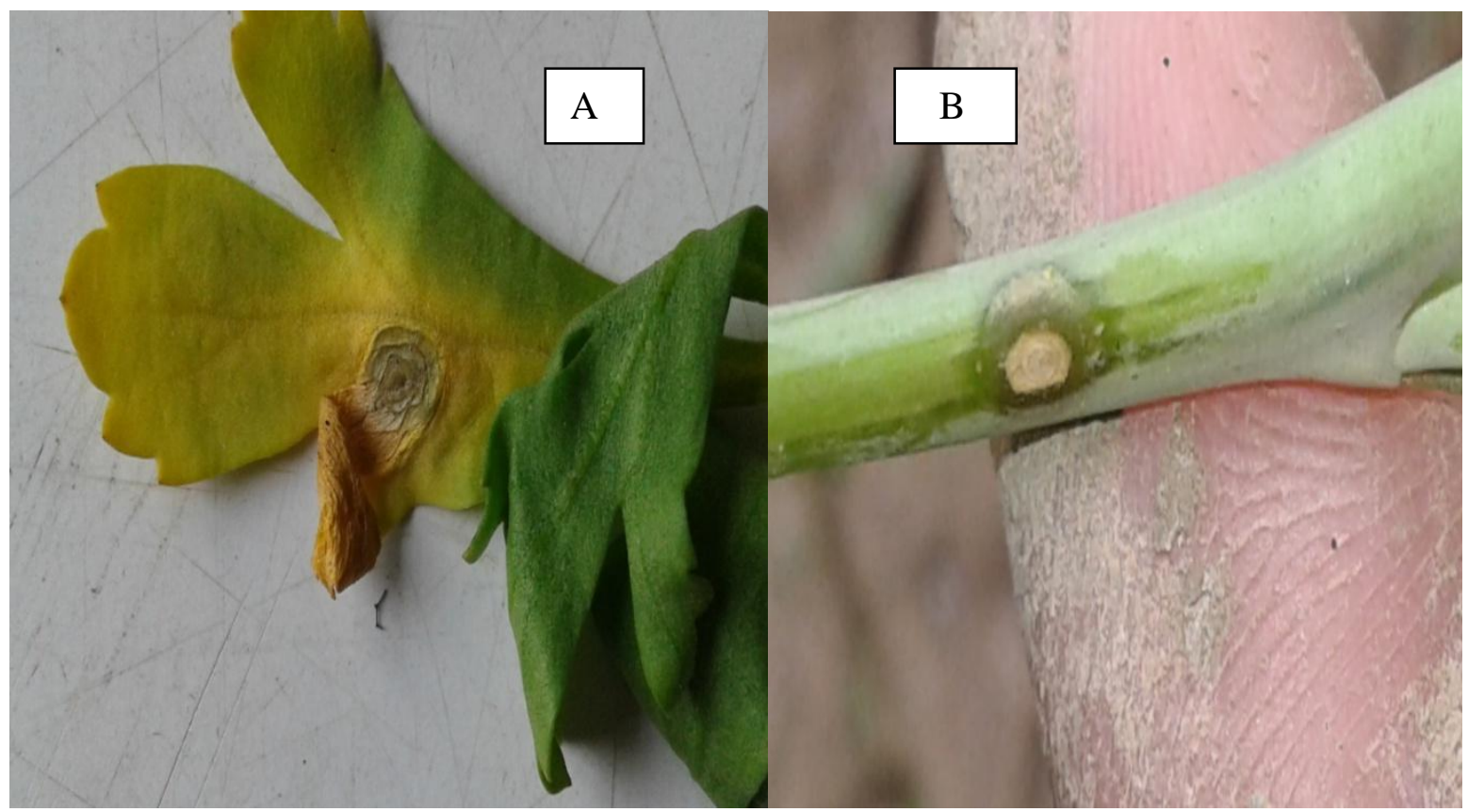

(A)Necrotic and concentric leaf spots at margin of leaf (B) Concentric spots on stem

Plate.2 Isolation and purification of Alternaria alternata

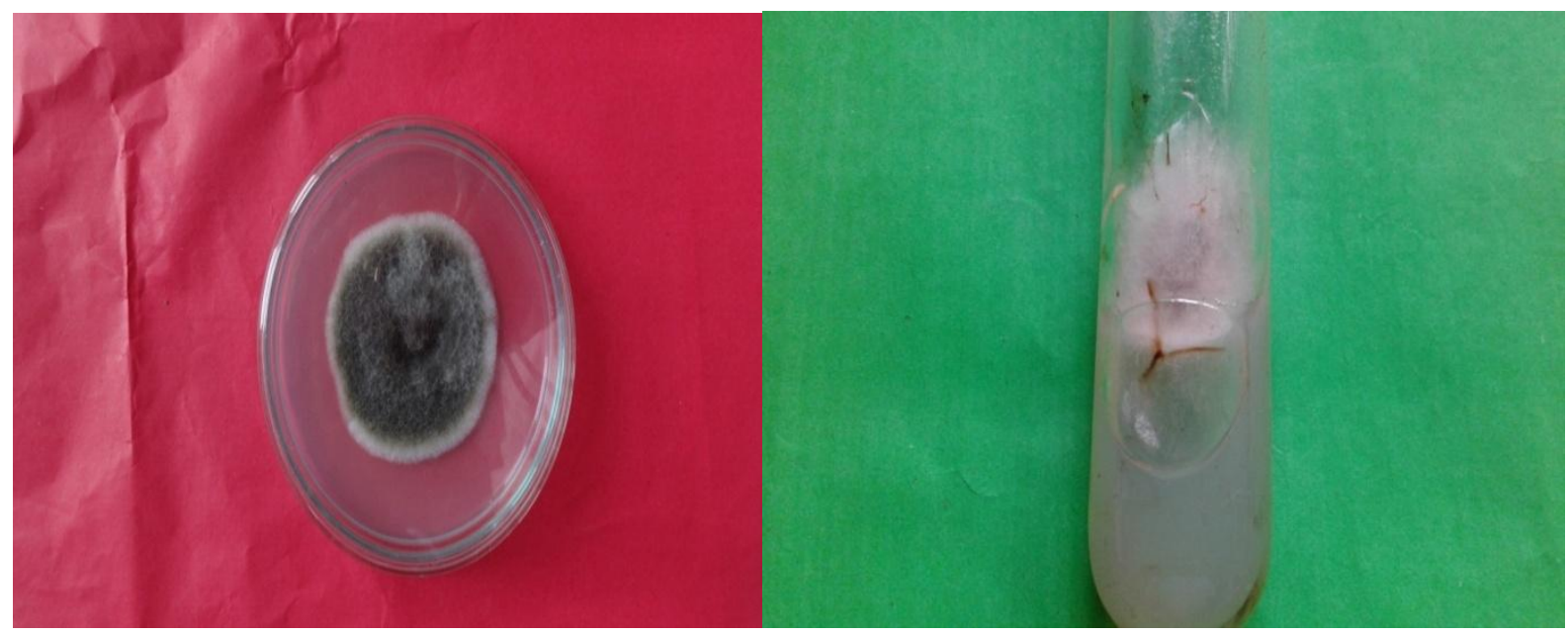


Plate.3 Different species of Trichoderma isolated from different crop rhizosphere

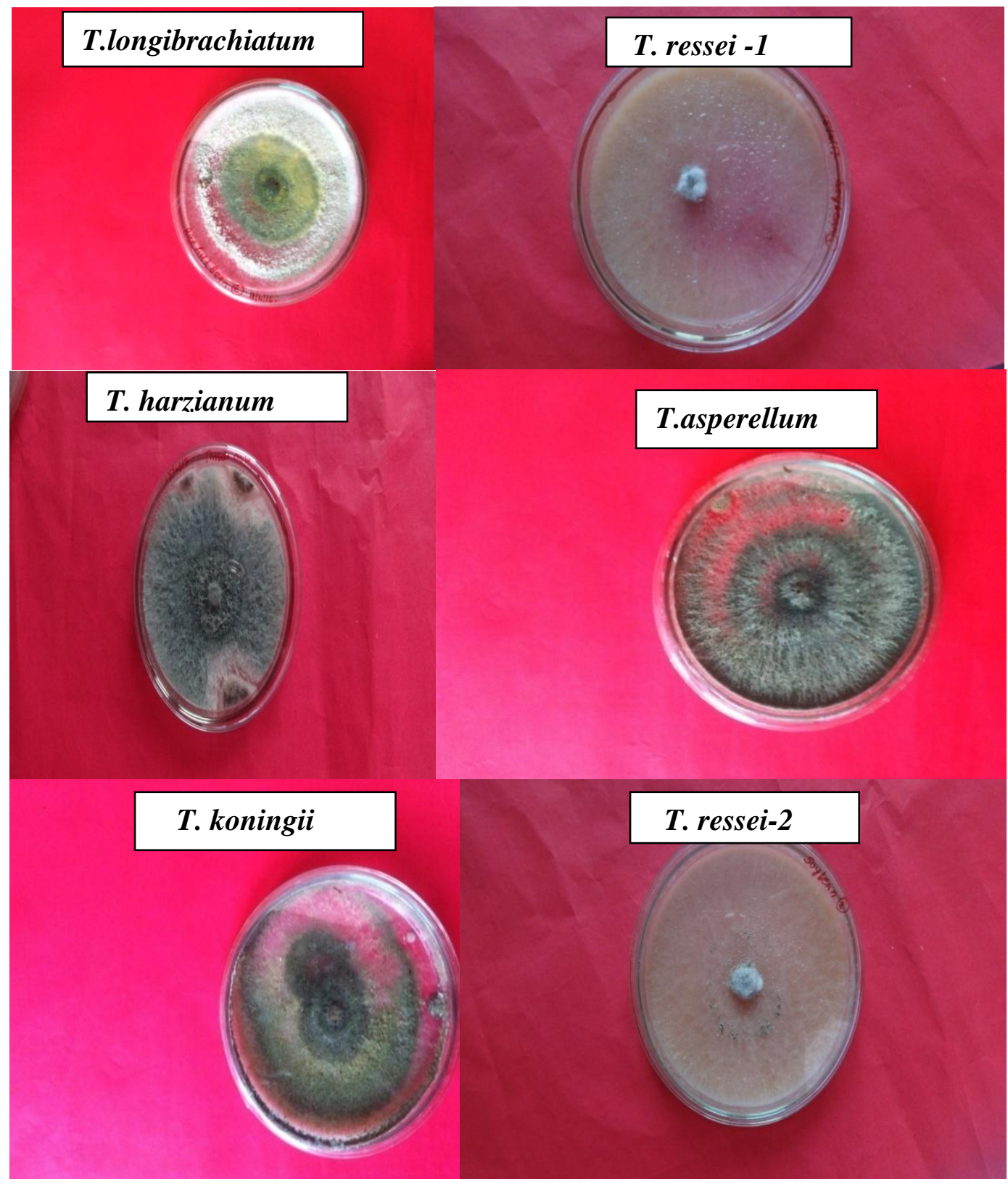


Plate.4 Suppression of mycelial growth of Alternaria alternata by Trichoderma species

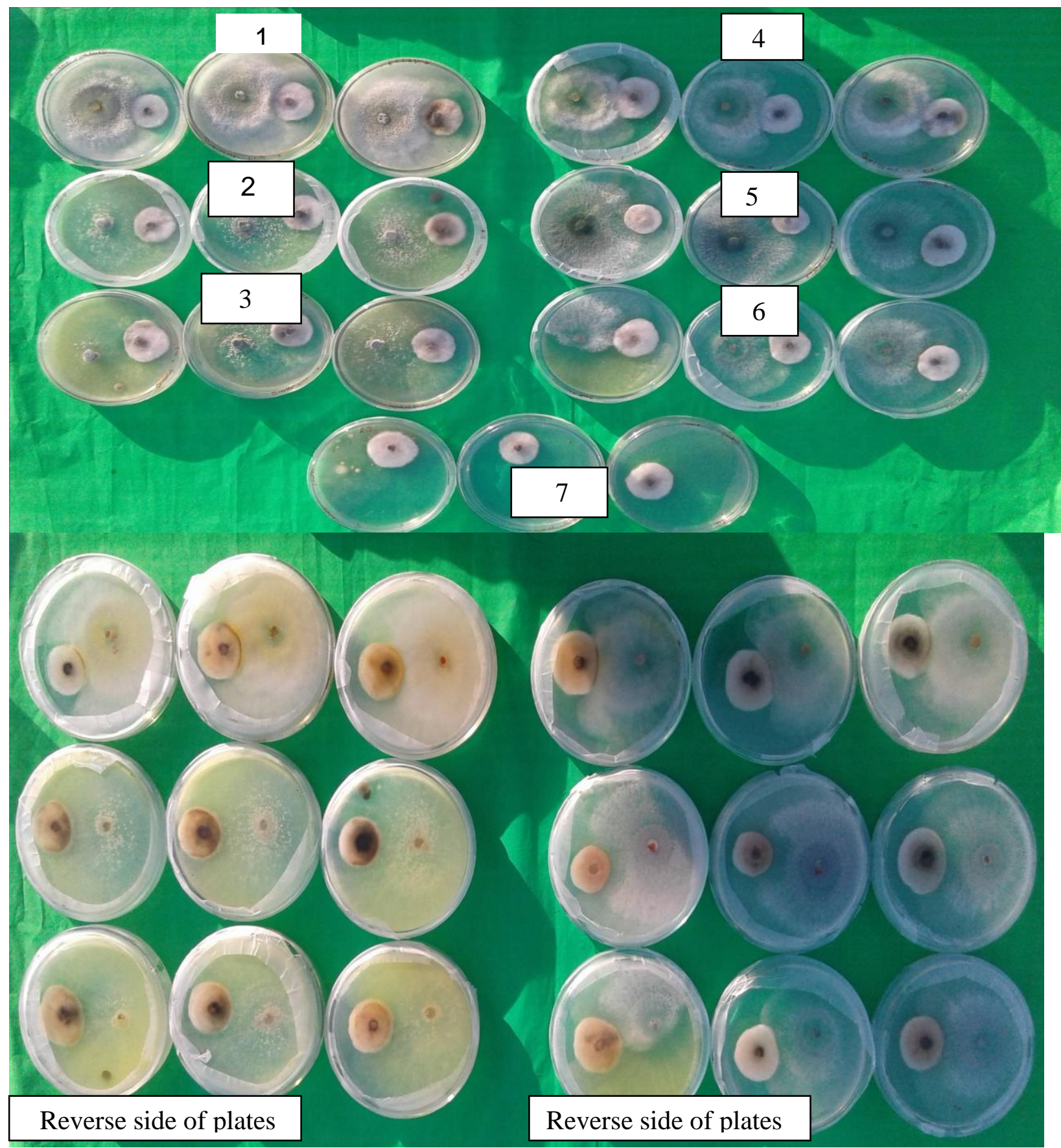

(1) T.longibrachiatum, (2) T. ressei-1, (3) T.ressei-2, (4) T. koningii, (5) T.asperellum, (6) T. harzianum (7)Control 
Plate.5 Evaluation of bioefficacy of culture filtrate of Trichoderma species against Alternaria alternata under in-vitro conditions

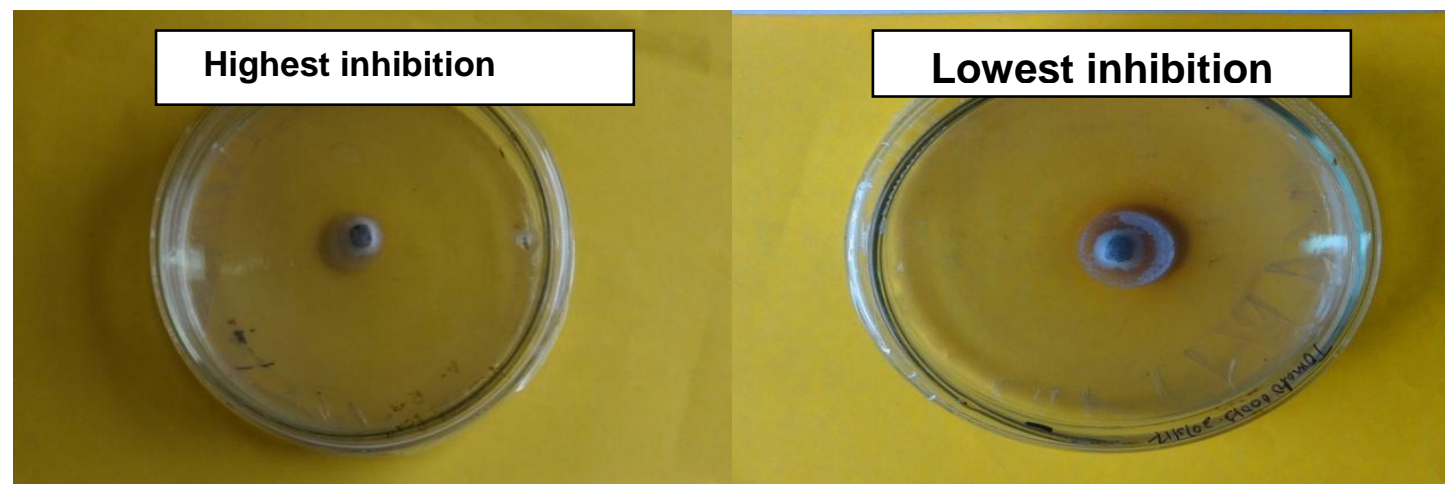

Plate.6 Evaluation of bioefficacy of culture filtrate of Trichoderma species amended with $\mathrm{ZnSO}_{4}$ against Alternaria alternata
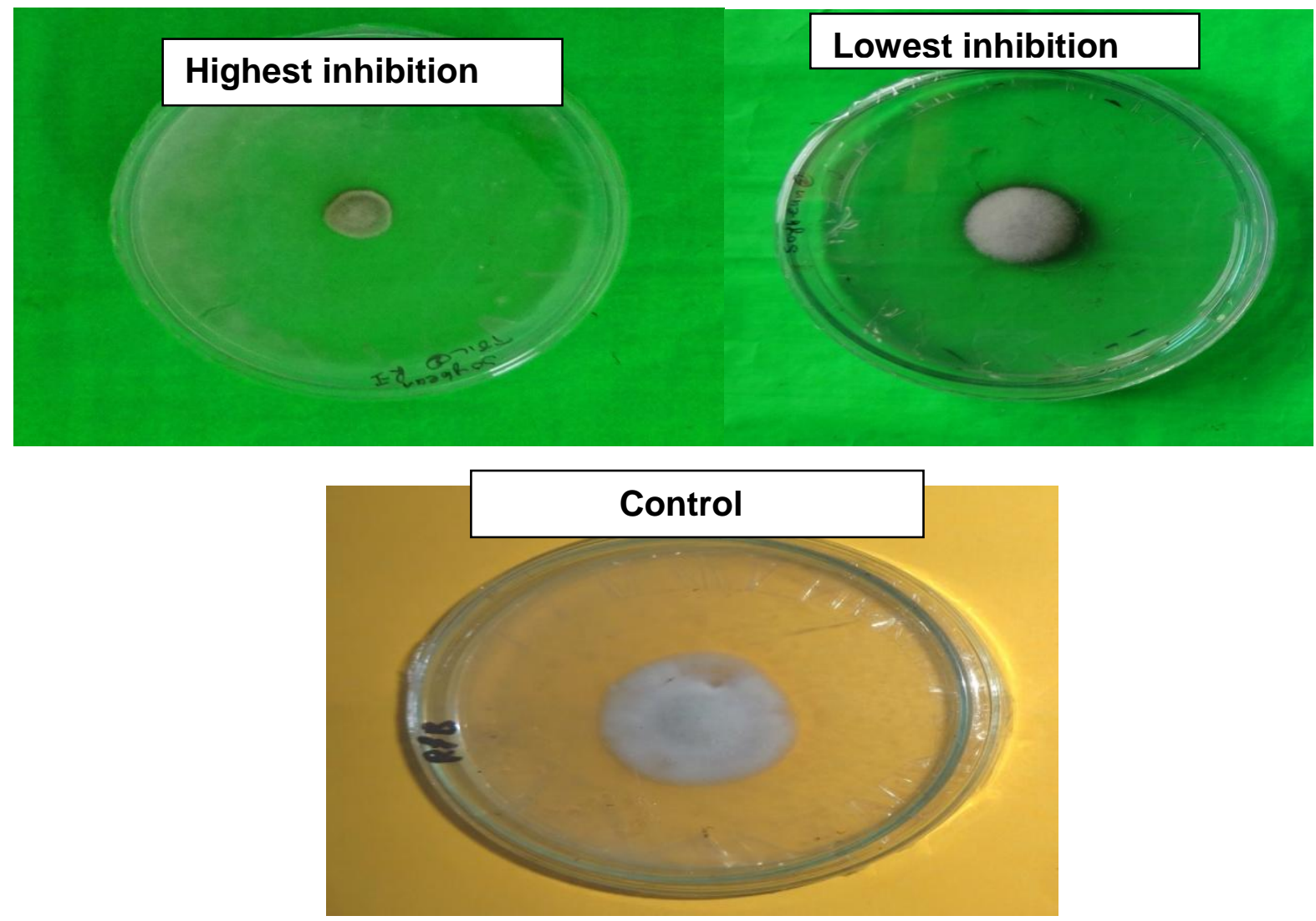
Plate.7 Multiplication of Trichoderma species in potato dextrose broth

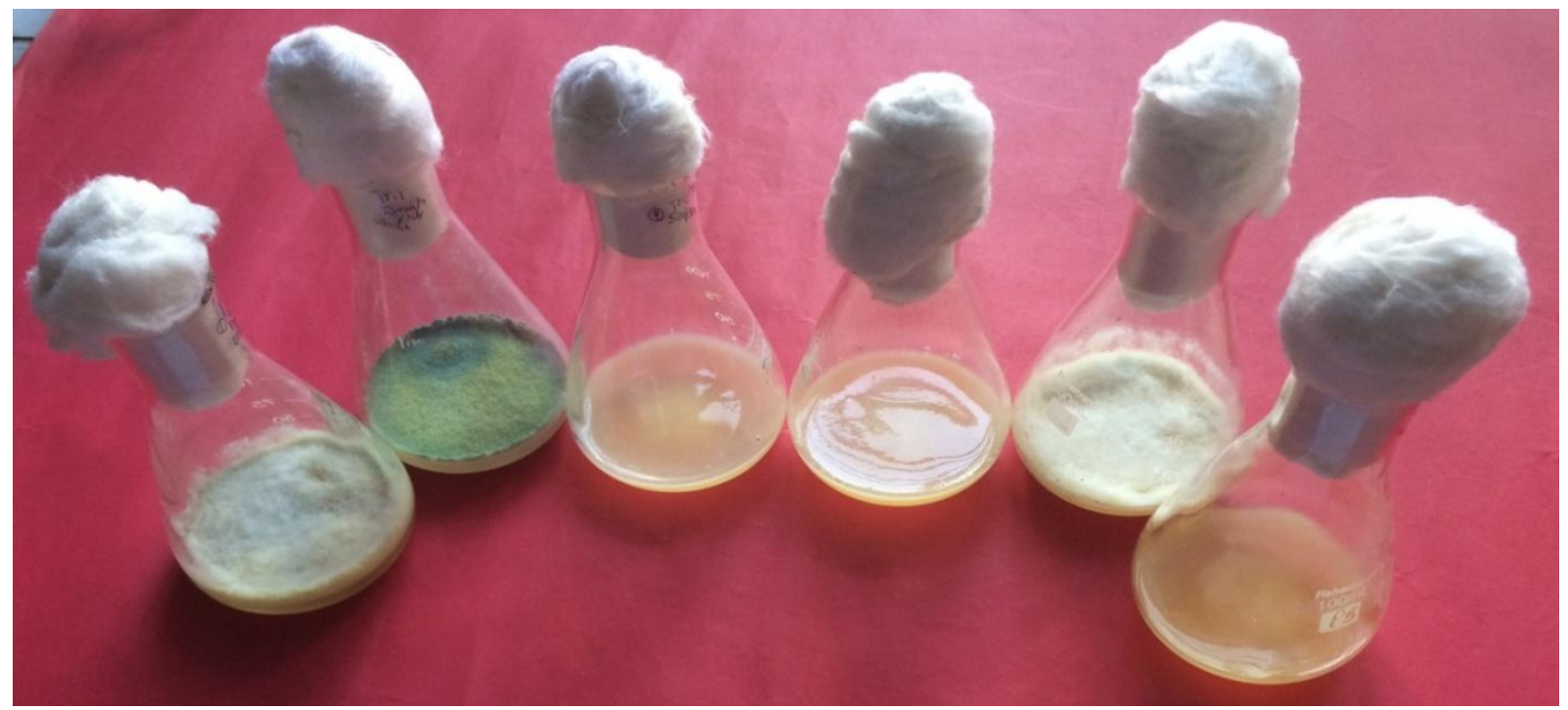

Plate.8 Multiplication of Trichoderma species in potato dextrose broth amended with $\mathrm{ZnSO}_{4}$

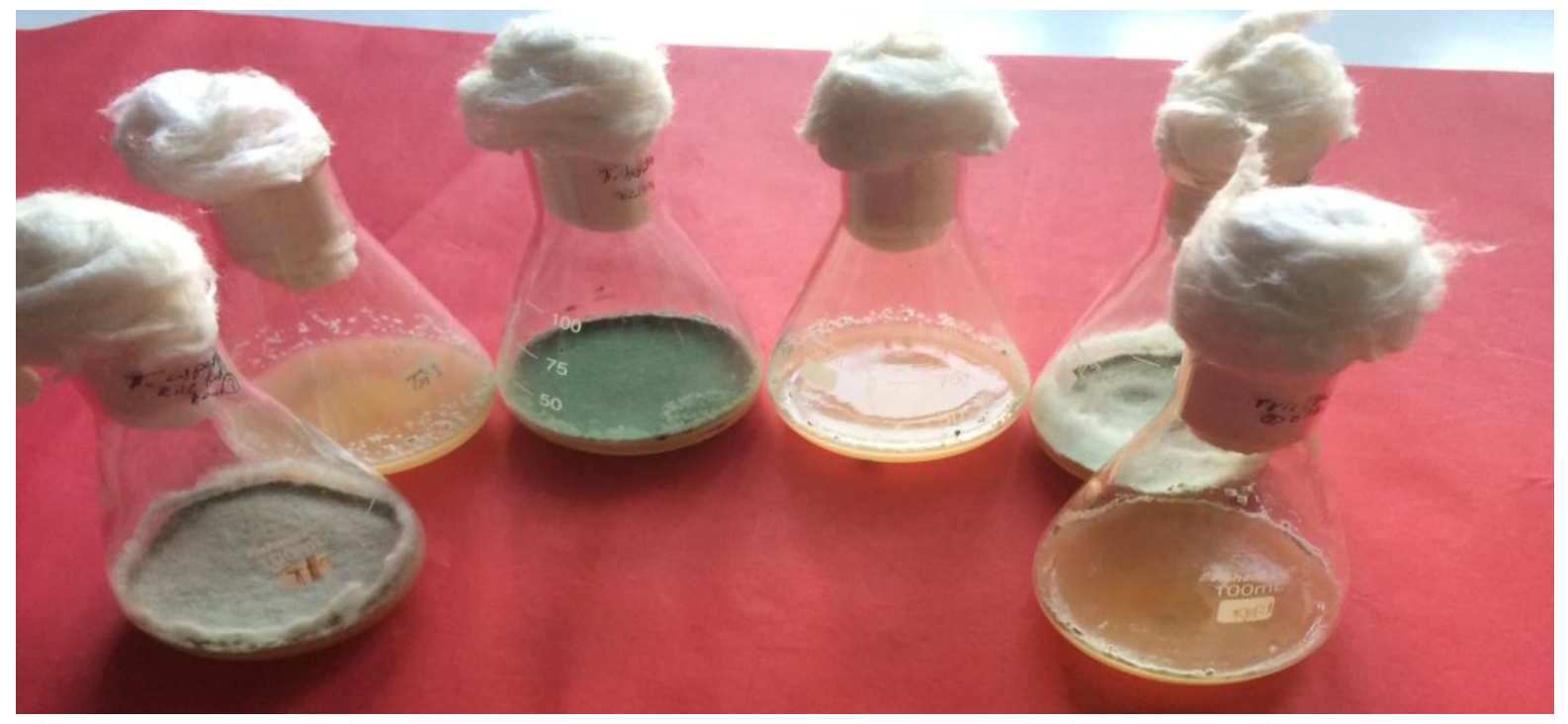


Table.1 Qualitative characterization of beneficial attributes of plant growth promoting rhizosphere fungi

\begin{tabular}{|l|l|l|l|}
\hline $\begin{array}{c}\text { PGPF isolates } \\
\text { different Rhizosphre } \\
\text { soils }\end{array}$ & IAA Producing activity & $\begin{array}{c}\text { Phosphorus } \\
\text { solublizing activity }\end{array}$ & $\begin{array}{l}\text { Ammonia Producing } \\
\text { activity }\end{array}$ \\
\hline T. koningii & +++ (dark pink) maximum & + (minimum) & ++ (deep yellow) medium \\
\hline T.ressei-1 & +++ (dark pink) maximum & - absent & + (faint yellow) minimum \\
\hline T.asperellum & ++ (faint pink) medium & + (minimum) & + (faint yellow) minimum \\
\hline T. harzianum & ++ (faint pink) medium & + (minimum) & + (faint yellow) minimum \\
\hline T.longibrachiatatum & +++ (dark pink) maximum & - absent & + (faint yellow) minimum \\
\hline T.ressei-2 & ++ (faint pink)medium & - absent & ++ (deep yellow) medium \\
\hline
\end{tabular}

Table.2 Screening of different Trichoderma species against Alternaria alternata under in-vitro conditions

\begin{tabular}{|c|c|c|c|c|c|}
\hline \multirow[t]{2}{*}{ Trichoderma species } & \multicolumn{5}{|c|}{ Growth in (mm) } \\
\hline & 48hours & 72hours & 96hours & mean & $\begin{array}{l}\text { Percentage } \\
\text { inhibition }\end{array}$ \\
\hline $\mathrm{T}_{1}$ (T.koningii) & $27.73(21.66)$ & $31.52(27.33)$ & $23.57(16.00)$ & 27.61 & 24.99 \\
\hline $\mathrm{T}_{2}($ T.ressei-1) & $27.50(21.33)$ & $25.90(19.33)$ & $13.34(5.33)$ & 22.24 & 39.58 \\
\hline$T_{3}($ T.harzianum $)$ & $27.62(21.50)$ & $30.43(25.66)$ & $22.51(14.66)$ & 26.85 & 27.05 \\
\hline$T_{4}($ T.asperellum $)$ & $26.80(20.33)$ & $20.60(12.66)$ & $23.82(16.33)$ & 23.74 & 35.50 \\
\hline $\mathrm{T}_{5}$ (T.longibrachiatum) & $27.03(20.66)$ & $24.81(17.66)$ & $21.69(13.66)$ & 24.51 & 33.41 \\
\hline $\mathrm{T}_{6}($ T.ressei-2) & $27.15(20.83)$ & $25.45(18.66)$ & $13.34(5.33)$ & 21.98 & 40.28 \\
\hline Control & $31.08(26.66)$ & $36.45(35.33)$ & $42.89(46.33)$ & 36.81 & - \\
\hline Mean & 27.84 & 27.88 & 23.02 & & \\
\hline $\mathbf{C V}$ & 7.14 & & & & \\
\hline Fungus $\mathrm{CD}(\mathrm{P} \leq \mathbf{0 . 0 5})$ & 1.78 & & & & \\
\hline Hours $\mathrm{CD}(\mathrm{P} \leq 0.05)$ & 1.17 & & & & \\
\hline Fungus x Hours & 3.09 & & & & \\
\hline
\end{tabular}

The values in the parenthesis are original value

Table.3 Evaluation of bioefficacy of culture filtrates of Trichoderma species against Alternaria alternata under in-vitro conditions.

\begin{tabular}{|c|c|c|c|c|c|c|}
\hline \multirow[t]{2}{*}{ Trichoderma species } & \multicolumn{6}{|c|}{ Growth in (mm) } \\
\hline & 48hours & 72hours & 96hours & 120hours & mean & $\begin{array}{l}\text { Percentage } \\
\text { inhibition }\end{array}$ \\
\hline $\mathbf{T}_{1}($ T.koningii) & $26.68(20.16)$ & $26.80(20.33)$ & $26.80(20.33)$ & $27.50(21.33)$ & 26.94 & 30.53 \\
\hline $\mathrm{T}_{2}($ T.ressei-1) & $24.84(17.66)$ & $25.47(18.50)$ & $25.72(18.83)$ & $26.68(20.16)$ & 25.68 & 33.78 \\
\hline $\mathbf{T}_{3}($ T.harzianum $)$ & $25.96(19.16)$ & $27.03(20.66)$ & $27.03(20.66)$ & $28.52(22.83)$ & 27.14 & 30.01 \\
\hline $\mathbf{T}_{4}($ T.asperellum $)$ & $22.51(14.66)$ & $23.18(15.50)$ & $24.34(17.00)$ & $24.97(17.83)$ & 23.75 & 38.75 \\
\hline $\mathbf{T}_{5}($ T.longibrachiatum $)$ & $27.03(20.66)$ & $27.03(20.66)$ & $27.74(21.66)$ & $28.19(22.33)$ & 27.50 & 29.08 \\
\hline $\mathrm{T}_{6}($ T.ressei-2) & $22.78(15.00)$ & $25.96(19.16)$ & $27.13(20.83)$ & $26.44(19.83)$ & 25.58 & 34.03 \\
\hline Control & $30.00(25.00)$ & $35.03(33.00)$ & $41.84(44.50)$ & $48.25(55.67)$ & 38.78 & - \\
\hline Mean & 25.69 & 27.22 & 28.66 & 30.08 & & \\
\hline $\mathbf{C V}$ & 2.23 & & & & & \\
\hline FungusCD $(\mathrm{P} \leq 0.05)$ & 0.51 & & & & & \\
\hline Hours $(\mathbf{P} \leq \mathbf{0 . 0 5})$ & 0.38 & & & & & \\
\hline Fungus $x$ Hours & 1.02 & & & & & \\
\hline
\end{tabular}


The values in the parenthesis are original value transformed into arch sin

Table.4 Evaluation of bioefficacy of culture filtrates of Trichoderma species amended with $\mathrm{ZnSO}_{4}$ against Alternaria alternata

\begin{tabular}{|c|c|c|c|c|c|c|}
\hline \multirow{2}{*}{ Trichoderma species } & \multicolumn{6}{|c|}{ Growth in (mm) } \\
\hline & 48hours & 72hours & 96hours & 120hours & mean & $\begin{array}{l}\text { Percentage } \\
\text { inhibition }\end{array}$ \\
\hline $\mathbf{T}_{1}($ T.koningii) & (26.07) 19.33 & (27.03) 20.66 & (27.96) 22.00 & (28.42) 22.66 & 27.96 & 29.39 \\
\hline $\mathrm{T}_{2}($ T.ressei-1) & (26.03) 19.33 & (27.24) 21.00 & (27.94) 22.00 & (28.41) 22.66 & 27.41 & 30.78 \\
\hline $\mathbf{T}_{3}($ T.harzianum $)$ & (27.71) 21.66 & (28.18) 22.33 & (28.75) 23.16 & (29.54) 24.33 & 28.54 & 27.92 \\
\hline $\mathbf{T}_{4}($ T.asperellum $)$ & (23.04) 15.33 & (24.59) 17.33 & (25.09) 18.00 & (25.71) 18.83 & 24.61 & 37.85 \\
\hline $\mathbf{T}_{5}$ (T.longibrachiatum) & (25.96) 19.16 & (25.50) 21.33 & (28.65) 23.00 & (29.10) 23.66 & 27.80 & 29.79 \\
\hline $\mathbf{T}_{6}($ T.ressei-2) & (22.50) 14.66 & (23.31) 15.66 & (23.83) 16.33 & (25.35) 18.33 & 23.75 & 40.02 \\
\hline Control & (30.42) 25.66 & (36.45) 32.33 & (42.12) 45.00 & (49.41) 57.66 & 39.60 & \\
\hline Mean & 25.96 & 27.76 & 29.19 & 30.85 & & \\
\hline CV & 3.64 & & & & & \\
\hline FungusCD $(P \leq 0.05)$ & 0.84 & & & & & \\
\hline Hours $(P \leq 0.05)$ & 0.64 & & & & & \\
\hline Fungus x Hours & 1.69 & & & & & \\
\hline
\end{tabular}

Table.5 Effect of micro-nutrient on biomass production of beneficial fungi

\begin{tabular}{|l|c|c|c|c|c|c|c|c|}
\hline \multicolumn{4}{|c|}{ With $\mathbf{Z n S O}_{\mathbf{4}}$} & \multicolumn{4}{c|}{ Without $\mathrm{ZnSO}_{\mathbf{4}}$} \\
\hline Fungal bioagents & $\begin{array}{c}\text { Fresh } \\
\text { weight }\end{array}$ & $\begin{array}{c}\text { Dry } \\
\text { weight }\end{array}$ & $\begin{array}{c}\text { Biomass } \\
(\mathbf{\%})\end{array}$ & $\mathbf{p H}$ & $\begin{array}{c}\text { Fresh } \\
\text { weight }\end{array}$ & $\begin{array}{c}\text { Dry } \\
\text { weight }\end{array}$ & $\begin{array}{c}\text { Biomass } \\
(\boldsymbol{\%})\end{array}$ & pH \\
\hline T. koningii & $8.54(2.20)$ & $2.01(0.12)$ & $\mathbf{9 4 . 4 5}$ & $\mathbf{5 . 1}$ & $8.79(2.33)$ & $2.78(0.23)$ & $\mathbf{9 0 . 2 0}$ & $\mathbf{4 . 1}$ \\
\hline T.longibrachiatum & $8.68(2.28)$ & $2.06(0.13)$ & $\mathbf{9 4 . 1 0}$ & $\mathbf{5 . 0}$ & $8.99(2.44)$ & $3.20(0.31)$ & $\mathbf{8 7 . 0 0}$ & $\mathbf{5 . 8}$ \\
\hline T.asperellum & $8.24(2.05)$ & $2.19(0.13)$ & $\mathbf{9 3 . 2 3}$ & $\mathbf{3 . 8}$ & $8.75(2.31)$ & $2.29(0.16)$ & $\mathbf{8 8 . 9 3}$ & $\mathbf{3 . 8}$ \\
\hline T. reesei-1 & $8.27(2.07)$ & $2.47(0.18)$ & $\mathbf{9 1 . 1 2}$ & $\mathbf{5 . 8}$ & $12.98(5.04)$ & $1.98(0.12)$ & $\mathbf{9 7 . 6 0}$ & $\mathbf{5 . 1}$ \\
\hline T. reesei-2 & $13.11(5.15)$ & $2.11(0.13)$ & $\mathbf{9 7 . 4 4}$ & $\mathbf{5 . 2}$ & $12.00(4.32)$ & $2.16(0.15)$ & $\mathbf{9 6 . 4 6}$ & $\mathbf{4 . 1}$ \\
\hline T.harzianum & $7.89(1.84)$ & $1.89(0.11)$ & $\mathbf{9 3 . 6 7}$ & $\mathbf{3 . 7}$ & $8.06(1.96)$ & $2.19(0.15)$ & $\mathbf{9 2 . 0 3}$ & $\mathbf{3 . 9}$ \\
\hline CV & $\mathbf{0 . 6 5}$ & $\mathbf{4 . 5 1}$ & & & $\mathbf{0 . 1 9}$ & $\mathbf{2 . 2 2}$ & & \\
\hline CD(0.05) & $\mathbf{0 . 1 0}$ & $\mathbf{0 . 1 7}$ & & & $\mathbf{0 . 0 3}$ & $\mathbf{0 . 0 9}$ & & \\
\hline
\end{tabular}

Table.6 Effect of biological treatments on physiological and disease incidence of Asalio crop

\begin{tabular}{|c|c|c|c|c|}
\hline Fungal bioagents & $\begin{array}{l}\text { Relative water } \\
\text { content }(\%)\end{array}$ & $\begin{array}{l}\text { Chlorophyll } \\
\text { content(\%) }\end{array}$ & $\begin{array}{l}\text { Membrane } \\
\text { stability } \\
\text { index }(\%)\end{array}$ & $\begin{array}{c}\text { Percent } \\
\text { disease } \\
\text { index }(\%)\end{array}$ \\
\hline T. harzianum & 71.82 & 48.42 & 84.20 & 48.63 \\
\hline T. koningii & 66.90 & 45.14 & 86.15 & $46 . .66$ \\
\hline T. reesei-1 & 68.49 & 44.82 & 79.63 & 45.00 \\
\hline T.asperellum & 57.03 & 38.90 & 90.36 & 53.63 \\
\hline T.longibrachiatum & 53.32 & 38.39 & 88.51 & 52.00 \\
\hline T. reesei-2 & 60.76 & 43.53 & 68.82 & 34.32 \\
\hline Control & 48.31 & 25.39 & 94.49 & 54.33 \\
\hline $\mathrm{CV}$ & 0.46 & 0.03 & 0.01 & 0.45 \\
\hline Fungus $\mathrm{CD}(\mathrm{P} \leq \mathbf{0 . 0 5})$ & 0.50 & 0.02 & 0.02 & 0.38 \\
\hline
\end{tabular}


Figure.1 In vitro management of Alternaria alternata by Trichoderma species; (a) Dual culture;

(b) Poison food study; (c) Poison food amended with $\mathrm{ZnSO}_{4}$
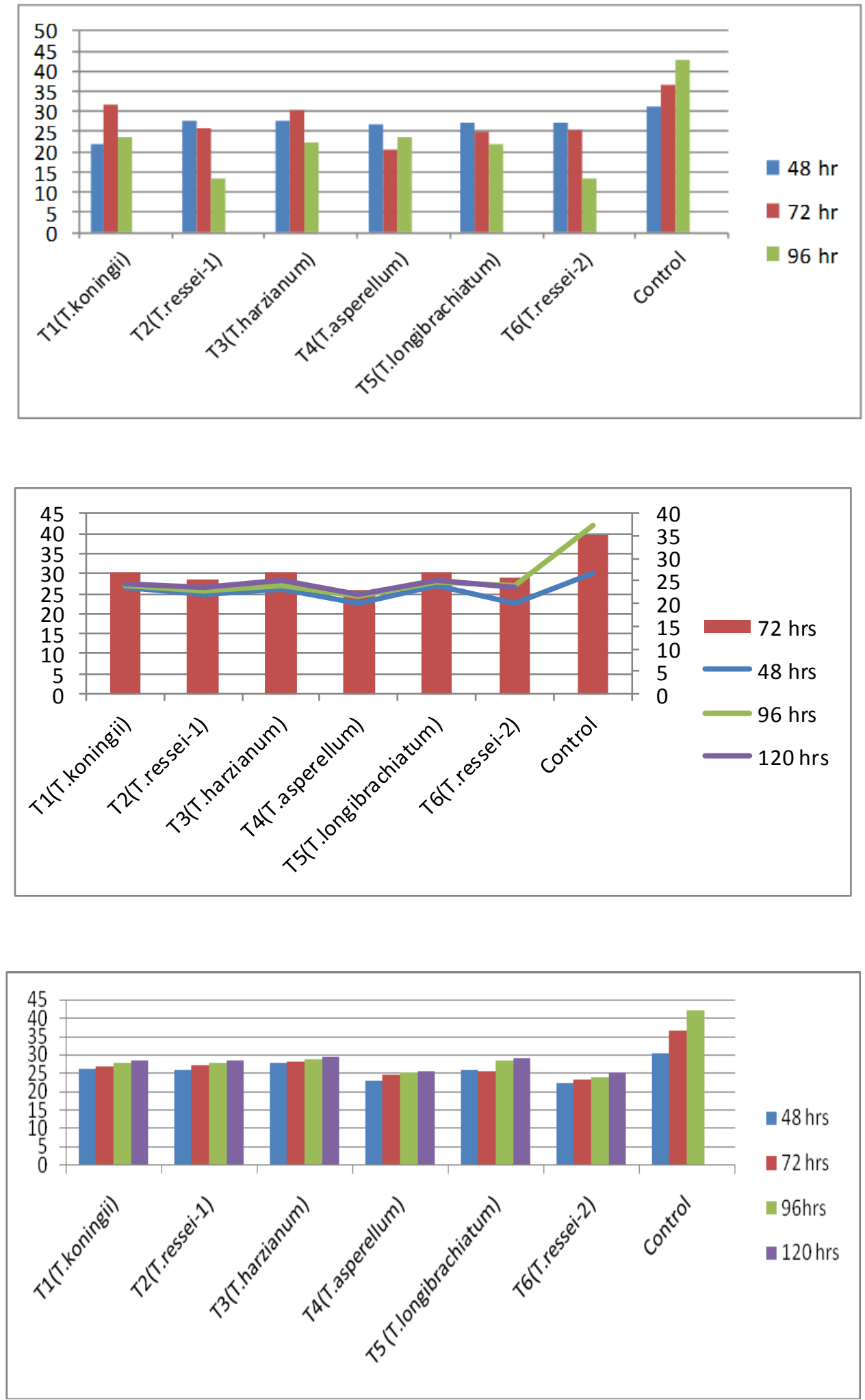
Figure.2 Effect of Tricoderma species on $\mathrm{ZnSO}_{4}$ on biological parameter and bio-control of Alternaria leaf blight

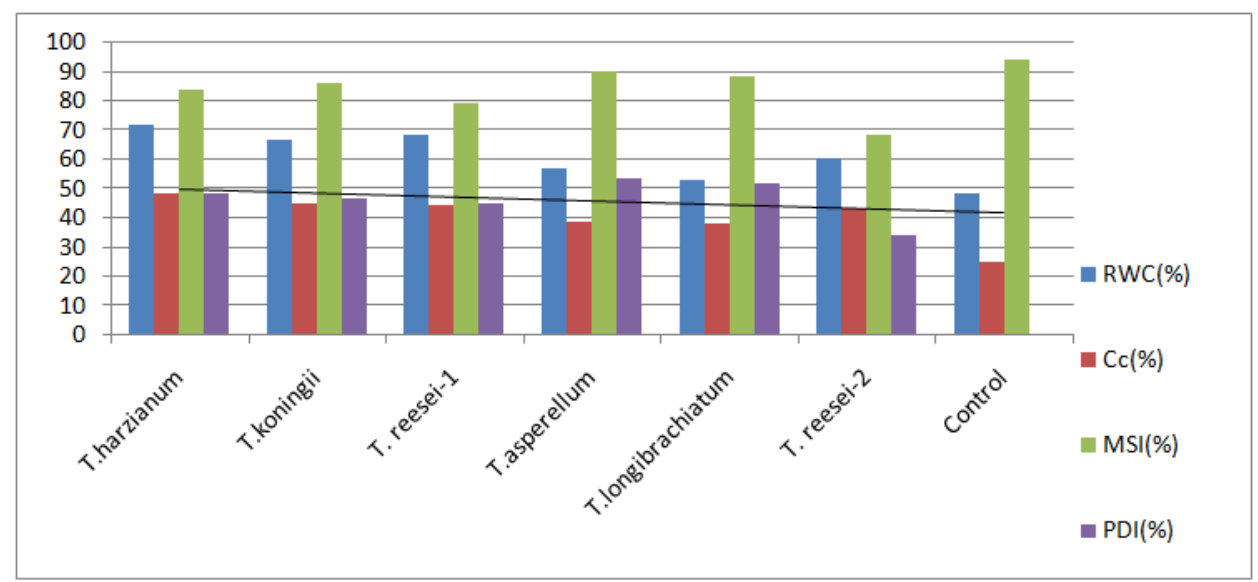

Effect of micro-nutrient on biomass production of beneficial fungi

To evaluate the effect of micro-nutrient on biomass production, the growth medium of beneficial fungus was amended with and without $\mathrm{ZnSO}_{4}$. The fresh weight of bioagents varied from 7.89 to $13.11 \mathrm{gm}$ while dry weight from $1.89 \mathrm{gm}$ to $2.47 \mathrm{gm}$ and $\mathrm{pH}$ from 3.7 to 5.8 in $\mathrm{ZnSO}_{4}$ amended growth medium. The highest (97.44\%) biomass production was recorded with $T$. ressei-2 while least $(91.12 \%)$ with T.ressei-1. However, almost identical but higher biomass production of $T$. koningii $(94.45 \%)$ and T.longibrachiatum $(94.10 \%)$ was recorded in $\mathrm{ZnSO}_{4}$ amended medium. The $\mathrm{pH}$ of Trichoderma species grown on $\mathrm{ZnSO}_{4}$ amended medium ranged from 3.7 to 5.8.

The highest T.ressei-2 (12.98gm) fresh weight and dry weight $(3.20 \mathrm{gm})$ of T.longibrachiatum was recorded in growth medium (potato dextrose broth)not amended with $\mathrm{ZnSO}_{4}$. However, the highest $(97.60 \%)$ biomass of $T$. reesei-1 was recorded in the same growth medium. The $T$. ressei-2 (96.46\%) was the next best to T.reesei-1 in biomass production followed by T.harzianum $(92.03 \%)$. The highest $\mathrm{pH}$ of Trichoderma species growth media potato dextrose broth was recorded (3.9 to 5.8) (Table 5).

Effect of biological treatments on physiological and disease incidence of Asalio crop

The effect of inoculation of fungal bioagent along with FYM and $\mathrm{ZnSO}_{4}$ was found significant on relative water content (RWC), chlorophyll content, membrane stability index (MSI) and disease index under in-vivo conditions. Although the highest (71.82\%) RWC was recorded in T. harzianum. Lowest (53.32) RWC was recorded in T.longibrachiatum. Similarly, the highest chlorophyll content (48.42) was recorded in T. harzianum which was statistically at-par with T.longibrachiatum (45.14) and T.reesei2.The lower and similar chlorophyll content was recorded in T. longibrachiatum (38.39) and $T$. asperellum(38.90). The minimum (68.82) MSI was recorded in T.ressei-2. The highest MSI was recorded in T. asperellum (90.36) that followed by $T$. longibrachiatum (88.51),T. koningii (86.00) but all similarly affected on MSI of Asalio crop. The minimum disease incidence was recorded T.ressei-2(34.32). 
The application of T.ressei-2+FYM+ZnSO and T.resse $i-1+\mathrm{FYM}^{2} \mathrm{ZnSO}_{4}$ was found effective in reducing the Alternaria leaf blight disease as it reduced disease incidence 34.32 (Table 6).

Different PGPF were isolated from the rhizosphere of different crops, the five isolates of six species of Trichoderma have been screened against Alternaria alternata under in-vitro and in-vivo conditions. All the tested bioagents showed significant mycelia growth suppressing ability under laboratory conditions and disease suppression under field conditions apart from positively affecting physiological parameters of crop. It has been reported that biocontrol agents having both antagonistic and plant growth promoting activity, could be more effective in controlling plant diseases (Borrero et al., 2006) and suppression of deleterious microorganisms in the rhizosphere (Sabuquillo et al., 2006).

The IAA producing activity of T.koningii, $T$. ressei-1 and T.longbrachiatum was maximum among the Trichoderma species. Trichoderma species was found to produce higher amount of ammonium. Moreover, medium ammonium production was record T.koningii. This could be due to the differential ability of bioagents to produce different enzymes and hormones. However, Oliveira et al., (2012)confirmed that the tested isolates from Trichoderma genus had the ability to solublize calcium phosphate. Rudresh and co-workers. (2005) reported that the different Trichoderma isolates solubilized insoluble tri-calcium phosphate (TCP) to various extents. Trichoderma viride (TV 97), Trichoderma virens (PDBCTVs 12) and Trichoderma virens (PDBCTV) solubilized $70 \%$ of that solubilzed by Bacillus megaterium. However, most of the Trichoderma genus isolates produce maximum indole acetic acid (IAA), with or without the L-tryptophan precursor has been reported by Oliveira et al., (2012).

The T.ressei-2 and T.ressei- 1 were highly and equally suppressive towards A. alternata, out of six species of Trichoderma. The T.asperellum was more suppressive than $T$. logibrachiatum but equal to T.ressei-1. The suppression of mycelia growth of test pathogen by different species of Trichoderma varied between $21.98 \mathrm{~mm}$ to $27.61 \mathrm{~mm}$. There was no significant increase in mycelia growth of the pathogen was recorded from 48 hours to 72 hours with exception to T.koningii and $T$. harzianum where growth of test pathogen increased but significant decrease was recorded at 96hours. The presence of an inhibition zone in dual culture suggests the secretion of diffusible non-volatile inhibitory substance/ mycoparasitism by the Trichoderma species. Previous studies have demonstrated that before mycelia of fungi interact, Trichoderma sp. produces low quantities of extracellular exochitinases (Brunner et al., 2003). Trichoderma strains inhibit the infections caused by plant pathogens using different biocontrol mechanisms like competition, antibiosis, mycoparasitism, hyphal interactions, and enzyme secretion (Poovendran et al., 2011).

The result obtained in poison food technique was different from that of dual culture technique. In poison food technique, the culture filtrate of Tasperellum was found highly inhibitory towards the test pathogen. The growth of the pathogen had increased with time but increase was comparatively slower from 72hours to 96hours but significantly increased at 120 hours in non $\mathrm{ZnSO}_{4}$ amended culture filtrate of Trichoderma species. The mycelia growth of A. alternata remained almost identical in culture filtrate of $T$. koningii and $T$. longibrachiatum from 48hours to 96 hours with minor increase at 120 hours. The growth 
of test pathogen in culture filtrates of T.asperellum was slower throughout the studied time to rest. Culture filtrate of Trichoderma species amended with $\mathrm{ZnSO}_{4}$ exhibited comparatively lower mycelial growth inhibition in comparison to non amended culture filtrate of Trichoderma species. Although the growth of the pathogen had increased with time but increase was comparatively slower after 96 hours to 120 hours. The growth of test pathogen in culture filtrates of T.ressei-2 remained slower throughout the studied time compared to rest Trichoderma species. Hajieghrari et al., (2008) evaluated six isolated of Trichoderma sp. against phytopathogenic fungi in dual culture techniques and through production of volatile and non-volatile inhibitors. The different effects of T.harzianum culture filtrates collected at different incubation times between tested pathogenic fungi due to T.harzianum ability to produce various defense enzymes and secondary metabolite containing antibiotics with varied nature, quantity and quality at different incubation times (Anita et al, 2012). Trichoderma spp. induces gene expression of proteins such as chitinase, glucanase, and peroxidase against antagonistic microbes (Hanson et al., 2004).

The fresh weight of bio-agents varied from 7.89 to $13.11 \mathrm{gm}$ while dry weight from 1.89 $\mathrm{gm}$ to $2.47 \mathrm{gm}$ and $\mathrm{pH}$ from 3.7 to 5.8 in $\mathrm{ZnSO}_{4}$ amended growth medium. The highest biomass production of $T$. reesei-2 was recorded with $\mathrm{ZnSO}_{4}$ while least identical with T.reesei-1. The highest fresh weight T.reesei-1 was recorded in growth medium not amended with $\mathrm{ZnSO}_{4}$. While highest biomass of $T$. ressei-1 was recorded in the same medium. The $T$. ressei-2 was next the best to $T$. ressei-1 in biomass production followed by T.harzianum. The $\mathrm{pH}$ of Trichoderma species grown on $\mathrm{ZnSO}_{4}$ amended medium ranged from 3.7 to 5.8. The lower $\mathrm{pH}$ of medium was recorded on which were grown in Trichoderma species in non zinc-sulphate amended medium. The change in biomass production by different bioagents could be due to the differential requirement for the micronutrient by the bioagent's. Similarly, change in $\mathrm{pH}$ may be due to the different metabolites produced by different pathogen and their reaction with $\mathrm{ZnSO}_{4}$. Mycelial growth can be stimulated by some heavy metals ( $\mathrm{Al}, \mathrm{Fe}, \mathrm{Mo}, \mathrm{Pb})$ and inhibited by others $(\mathrm{Cd}, \mathrm{Co}, \mathrm{Ni}, \mathrm{Se})$ was reported by Galus (1997). Copper salts, zinc salts, calcium hydroxide, potassium hydroxide and selected nitrogen sulfur and molybdenum compounds have been found to be highly toxic to pathogenic fungi. Metal ions applied at certain concentrations under laboratory conditions may lead to the death of the tested microorganisms, where in a natural environment they can stimulate microbial growth. The effects exerted by metal ions are determined by their chemical form availability and environmental factors (Durska, 2006).

\section{References}

Anita S, Ponmurugan P and Ganesh Babu R. 2012. Significance of secondary metabolites and enzymes secreted by Trichoderma atroviride isolates for the biological control of phomopsis canker disease 11(45): 10350-10357.

Barrs HD and Weatherley PE. 1962. A reexamination of the relative turgidity technique for estimating water deficits in leaves. Australian Journal of Biological Sciences 15:413-428.

Borrero C, Ordovas J, Trillas M I and Aviles M. 2006. Tomato Fusarium wilt suppressiveness. Soil Biology and Biochemistry 38: 1631-1637.

Brunner K, Peterbauer CK, Mach RL, Lorito $\mathrm{M}$, Zeilinger $\mathrm{S}$, and Kubicek RL. 2003. The Nacetylglucosaminidase of Trichoderma atroviride is essential for chitinase induction Trichoderma 
atroviride is essential for chitinases induction by chitin of and major relevance to biocontrol. Current Genetics 43,289-295.

Dennis C and Webster J. 1971. Antagonism properties of species groups of Trichoderma, III. Hyphal interaction. Transactions British Mycological Society 57: 363-369.

Deshmukh PS, Sairam RK and Shukla DS.1991. Measurement of ion leakage as a screening technique for drought resistance in wheat genotype. Indian Journal of Plant Physiology 34: 89-91.

Doke, S. and M. Guha, 2014. Garden cress (Lepidium sativum L.) Seed - An Important Medicinal Source: A Review. Scholars Research Library. J. Nat. Prod. Plant Resour, 4 (1):69-80

Durska G. 2006. Effect of copper and zinc on the growth of methylotrophic bacteria selected from the rhizospheric and non rhizospheric soil of barely. ZESz.Nauk.up Wroc.Rol 89(546)57,

Galus A.1997.Effect of chromium (III) and (vi) and its interactions with other metal on the mycelial biomass growth of aspergillus flavus. In: Microorganisms in the environment. occurrence activity and significance Ed. Barabasz169.

Hajieghrari B, Torabi-Giglou M, Mohammadi MR and Davari M. 2008. Biological potential of some Iranian Trichoderma isolates in the control of soil borne plant pathogenic fungi. African Journal of Biotechnology 7 (8):967972.

Hall IM and Bell JV. 1961. Further studies on the effect of temperature on the growth of some entomophthoraceous fungi. Journal of Insect Pathology 3: 289-296.

Hanson LE and Howell CR. 2004. Elicitors of plant defense responses from biocontrol strains of Trichoderma virens. Phytopathology 94: 171-176.

Harman, G.E., Howell, C.R., Viterbo, A., Chet, I. and Lorito, M. (2004a) Trichoderma species-opportunistic, avirulent plant symbionts. Nat. Rev. Microbiol. 2, 43-56

Johnson LF, Curl EA, Bond JH and Fribourg HA. 1959. Methods for studying soil microflora-plant disease relationship. Burgess publishing company, USA.

Moubasher A. 1993. Soil fungi in Qatar and other Arab countries. The Centre for Scientific and Applied Research, University of Qatar PP 566.

Oliveira AG, Chagas AFJ, Santos GR, Miller LO, Chagas LFB. 2012. Potential phosphate solubilization and AIA production of Trichoderma spp. Rev Verde Agroecol Desenvolv Sustent 7:149-155

Peng S, Garcia F, Laza R and Cassman KG. 1992. Leaf thickness affects the estimation of leaf $\mathrm{N}$ using a chlorophyll meter. International Rice Research Newsletter 17(16): 19-20.

Pikovskaya RI.1948. Mobilization of phosphorus in soil in connection with vital activity of some microbial species. Microbiology 1 7: 362-370.

Poovendran P, Kalaigandhi V, and Parivuguna V. 2011. In vitro study of antagonistic effect of Trichoderma sp, on tea plant pathogen, Phomopsis theae. Archives of Applied Science Research 3(4):352- 358

Rudresh DL, Shivaprakash MK and Prasad RD. 2005. Tricalcium phosphate solubilizing abilities of Trichoderma spp. in relation to $\mathrm{P}$ uptake and growth and yield parameters of chickpea (Cicer arietinum L.). Canadian Journal of Microbiology 51: 217-222. Sabuquillo P, De Cal A and Melgarejo P. 2006. Biocontrol of tomato wilt by Penicillium oxalicum formulations in different crop conditions. Biological 
Control 37: 256-265.

Sarwar M and Kremer RJ. 1995. Enhanced suppression of plant growth through production of L-tryptophan derived compounds by deleterious rhizobacteria. Plant Soil 172; 261269.

Smith NR and Daws UT. 1944. The bacteriostatic action of rose bengal in media used for plate counts of soil fungi. Soil Science 58: 467-471.

Valverde, A., A. Burgos, T. Fiscella, R. Rivas, E. Velazquez, C. Rodriguez and J.M. Igual, 2006. Differential effects of co inoculations with Pseudomonas jessenii PS06 (a phosphate solubilizing bacterium) and Mesorhizobium ciceri c-2/2 strains on the growth and seed yield of chickpea under greenhouse and field conditions. Plant Soil, 287: 43-50.

Vassilev N, Vassileva $\mathrm{N}$ and Nikolaeva I. 2006. Simultaneous P-solubilizing and biocontrol activity of microorganisms: potentials and future trends. Applied Microbiology and Biotechnology 71: 137-144.

\section{How to cite this article:}

Surya Prakash Redd, M., Vibha and Sunil Kumar Pandey 2018. Role of Root Colonizing Trichoderma Species in Management of Alternaria Leaf Blight of Asalio (Lepidium sativum L.) Caused by Alternaria alternata. Int.J.Curr.Microbiol.App.Sci. 7(07): 2544-2561. doi: https://doi.org/10.20546/ijcmas.2018.707.299 